International Journal of Life Sciences
Available online at www.sciencescholar.us
Vol. 5 No. 3, December 2021, pages: $156-163$
e-ISSN: 2550-6986, p-ISSN: $2550-6994$
https://doi.org/10.53730/ijls.v5n3.1608

\title{
Performance of Native Chicken Feed with Different Types of Oil Substitution
}

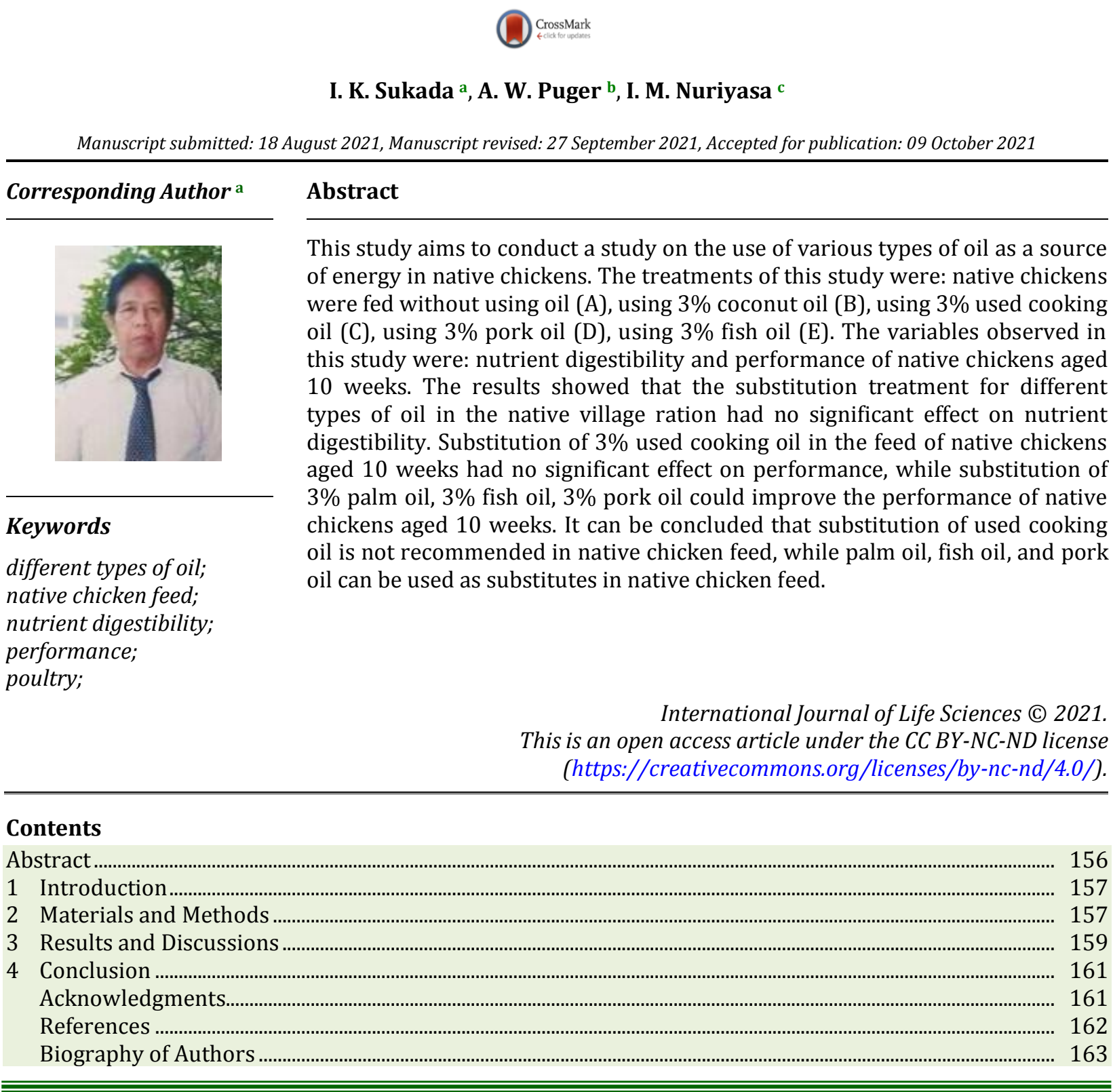

\footnotetext{
a Udayana University, Denpasar, Indonesia

b Udayana University, Denpasar, Indonesia

c Udayana University, Denpasar, Indonesia
} 


\section{Introduction}

The use of oil in the feed can reduce dusty conditions in the feed and can increase the palatability of the feed (Zhang et al., 2015; Estévez \& Cava, 2006). There are several types of oil as an energy source with different nutrient content, very useful micronutrients such as omega 3 , and even some sources of oil that contain substances that can harm livestock and consumers. Oil as an energy source that can be used in formulating rations includes: coconut oil, used cooking oil, pork oil, and fish oil.

The oil in poultry feed not only helps meet the high energy needs but also increases the appetite of the poultry (Yegani \& Korver, 2008). Oil can help the process of absorption of fat-soluble vitamins and reduce dustiness in the ration. Fish oil is a fat fraction obtained from fish extraction or as a by-product of the fish canning industry which is produced due to heating and sterilization during the process so that the oil from fish is extracted and wasted along with heat. Fish oil is recommended for a healthy diet because it contains many unsaturated fatty acids with many omega-3 double bonds (PUFA), namely EPA and DHA which are beneficial for the body (Aidos, 2002).

Fish oil is a great source of essential fatty acids. Essential fatty acids are fatty acids that cannot be synthesized by the body so they need to be added through the diet. Substitution of fish oil into feed can produce livestock products that are high in omega-3 fatty acids because fish oil contains omega- 3 fatty acids. The use of fish oil in feed is one of the efforts made to increase the productivity of native chickens. Researchers hope to improve the performance of native chickens through the use of various oils as an energy source.

\section{Materials and Methods}

The study used a completely randomized design (CRD), with 4 treatments and 5 replications. Each experimental unit used five native chickens so that the total number of native chickens used was 100 birds. Feed treatment consisted of: feed without using oil (A); supplementation of $3 \%$ palm oil in feed (B); supplementation of $3 \%$ used cooking oil in feed (C); supplementation of $3 \%$ pork oil in feed (D); supplementation of $3 \%$ fish oil in feed (E).

\section{Research feed}

The feed was prepared from yellow corn, concentrate, rice bran, and different types of oil (palm oil, cooking oil, pork oil, fish oil) $\mathrm{NaCl}$, mineral mix. All rations were prepared with the same energy content (2800 $\mathrm{kcal} / \mathrm{kg}$ ) and the same protein (16\%).

Table 1

Feed composition and nutrient content of research feed

\begin{tabular}{llllll}
\hline $\begin{array}{l}\text { Feed Ingredients } \\
(\%)\end{array}$ & \multicolumn{5}{c}{ Treatment } \\
\cline { 2 - 6 } & $\mathrm{A}$ & $\mathrm{B}$ & $\mathrm{C}$ & $\mathrm{D}$ & $\mathrm{E}$ \\
\hline Yellow Corn & 50 & 24 & 24 & 25.5 & 26 \\
Concentrate & 38 & 34 & 31.5 & 30 & 29.5 \\
Rice bran & 11.3 & 38.3 & 41.5 & 41.5 & 41.5 \\
Salt & 0.2 & 0.2 & 0.2 & 0.2 & 0 \\
Mineral Mix & 0.5 & 0.5 & 0.5 & 0.5 & 0 \\
Palm oil & 0 & 3.0 & 0 & 0 & 0 \\
Cooking Oil & 0 & 0 & 3.0 & 0 & 0 \\
Pork Oil & 0 & 0 & 0 & 3.0 & 0 \\
Fish oil & 0 & 0 & 0 & 0 & 3.0 \\
Total & 100 & 100 & 100 & 100 & 100 \\
Nutrient*) & & & & & \\
\hline
\end{tabular}

Sukada, I. K., Puger, A. W., \& Nuriyasa, I. M. (2021). Performance of native chicken feed with different types of oil substitution. International Journal of Life Sciences, 5(3), 156-163. https://doi.org/10.53730/ijls.v5n3.1608 


\begin{tabular}{lccccc}
\hline ME (Kkal/kg) & 2801.60 & 2800.60 & 2800.95 & 2801.95 & 2803.95 \\
Crude Protein (\%) & 16.08 & 16.54 & 16.39 & 16.17 & 16.18 \\
Ca (\%) & 0.78 & 0.73 & 0.68 & 0.65 & 0.65 \\
Pav (\%) & 0.46 & 0.45 & 0.43 & 0.41 & 0.41 \\
Lipid (\%) & 4.19 & 6.62 & 6.89 & 6.93 & 6.94 \\
Crude Fiber (\%) & 3.01 & 5.57 & 5.93 & 5.94 & 5.94 \\
\hline
\end{tabular}

Explanation:

Nutrient content of feed based on the results of the proximate analysis in the Laboratory of Nutrition and Animal Feed, Faculty of Animal Husbandry, Udayana University

A: feed without using oil;

B: feed using $3 \%$ cooking oil substitution

C: feed using $3 \%$ palm oil substitution

D: feed using $3 \%$ pork oil substitution

E: feed using $3 \%$ fish oil substitution

Variable

Nutrient digestibility

Dietary dry matter digestibility and nutrient content digestibility were calculated by the total collection method. This method was carried out on naive chickens aged 10 weeks. The excreta were collected and dried in the sun, then baked at a temperature of $\left(100^{\circ} \mathrm{C}-105^{\circ} \mathrm{C}\right)$ for five hours until the excreta were dry. The energy content of excreta can be determined by bomb calorimeter and protein excretion is determined by Kjelldhal analysis. Dietary dry matter digestibility and nutrient digestibility were calculated by the formula:

$$
\mathrm{KC}=\frac{(\mathrm{A}-\mathrm{B})}{\mathrm{A}} \times 100 \%
$$

Information:

KC : Nutrient Digestibility (\%)

A : Consumption of dry matter or nutrient feed (g)

B : Amount of dry matter or nutrient excreta (g)

\section{Cholesterol}

Blood serum cholesterol was calculated using the Boehringer method (Boehringer, 1996). Duck blood samples were put into sterile test tubes and then centrifuged at $2500 \mathrm{rpm}$ for 10 minutes. The supernatant is the form of serum that was taken using a microscope and then put into a microtube, then it was ready to be analyzed for cholesterol content using the Enzymatic Cholesterol High-Performance method.

\section{Growth rate}

The bodyweight of native chickens at the beginning of the study was obtained by weighing at the beginning of the study before the chickens were given treatment. The final native chicken body weight was obtained from weighing at the end of the study (Geng et al., 2020; Haunshi et al., 2011). Weight gain was obtained by subtracting the final body weight from the initial bodyweight of the study. The ration consumption was measured once a week by calculating the difference between the amount of feed given and the rest of the feed. Feed conversion ratio (FCR) is the ratio between the amounts of feed consumed and body weight gain. FCR is a benchmark for assessing the level of efficiency in the use of feed. 


\section{Results and Discussions}

The results showed that native chickens that received feed treatment without using oil substitution (A) resulted in a protein digestibility of 74.47\%, while the diet used cooking oil (B), used palm oil (C), used fish oil (D), and used fish oil (D). lard (E) $0.68 \%$ each; 0.91\%; 1.61\%; $1.98 \%$ higher $(\mathrm{P}>0.05)$ than treatment $\mathrm{A}$. Treatment E caused the efficiency of GE to change to DE $85.78 \%$, treatment D, C, B and A were $0.93 \%: 2.02 \%$ respectively ; $2.16 \%$ and $0.28 \%$ lower $(\mathrm{P}>0.05)$ than $\mathrm{E}$. The highest protein digestibility occurred in treatment A, which was $70.73 \%$, while treatments B, C, D, and E were 2, respectively. $39 \%, 1.09 \% ; 0.03 \%$ and $0.82 \%$ lower $(\mathrm{P}>0.05)$ than $\mathrm{A}$.

Table 2

Nutrient Digestibility of Native Chickens Feeds with Different Oil Substitutions

\begin{tabular}{lllllll}
\hline \multirow{2}{*}{ Variable } & \multicolumn{5}{c}{ Treatment $^{1)}$} & \multicolumn{2}{c}{ SEM $^{2}$} \\
\cline { 2 - 6 } & $\mathrm{A}$ & $\mathrm{B}$ & $\mathrm{C}$ & $\mathrm{D}$ & $\mathrm{E}$ & \\
\hline Dry Matter Digestibility (\%) & $74.47^{\mathrm{a} 3)}$ & $74.98^{\mathrm{a}}$ & $75.15^{\mathrm{a}}$ & $75.67^{\mathrm{a}}$ & $75.95^{\mathrm{a}}$ & 0.76 \\
Efficiency of Converting GE to DE (\%) & $85.54^{\mathrm{a}}$ & $83.93^{\mathrm{a}}$ & $84.05^{\mathrm{a}}$ & $84.98^{\mathrm{a}}$ & $85.78^{\mathrm{a}}$ & 0.57 \\
Crude Protein Digestibility (\%) & $70.73^{\mathrm{a}}$ & $69.04^{\mathrm{a}}$ & $69.96^{\mathrm{a}}$ & $70.71^{\mathrm{a}}$ & $70.15^{\mathrm{a}}$ & 1.04 \\
\hline
\end{tabular}

Information:

1) Feed treatment without using oil substitution (A); using cooking oil (B); using palm oil (C); using fish oil (D); using pork oil (E)

2) Standard Error of the Treatment Means

3) Different letter superscript letters in the same line showed significant differences $(\mathrm{P}<0.05)$

Treatment using different oil substitutions in native chicken feed did not significantly affect nutrient digestibility (Jayasena et al., 2015). Digestibility can be the first measure of the high and low nutritional value of a feed ingredient. Bagiarta et al. (2017), stated that the digestibility of the ration material was influenced by the crude fiber content of the ration, the chemical composition of the ration constituents, the protein level of the ration, the physical form of the ration, and the amount of ration consumed. The crude fiber content of feed $\mathrm{A}, \mathrm{B}, \mathrm{C}, \mathrm{D}$, and $\mathrm{E}$ is not much different and is still in the recommended range. Nutrient digestibility is closely related to the crude fiber content of the ration (Mountzouris et al., 2010; Amad et al., 2011). The higher the crude fiber, the lower the digestibility of the feed. Table 1 shows that the crude weight content of treatment A, B, C, D, and E is below the maximum allowable standard. The results of Puger \& Nuriyasa (2019), research using fermented wine waste in ducks got the same results.

The results showed that the bodyweight of native chickens at the beginning of the study who received ration treatment without using oil (A), 100.49g, used cooking oil (B), palm oil (C), fish oil (D), and pork oil (E) respectively. $-100,490 \mathrm{~g}$ each; 99.04g; 104.20g; 101.23g; and 102.03g which were not statistically significant $(\mathrm{P}>0.05)$. It is developed that the original chicken used at the beginning of the study was homogeneous.

Table 3

Performance of native chickens that get feed treatment with different types of substitution

\begin{tabular}{lllllll}
\hline \multirow{2}{*}{ Variable } & \multicolumn{5}{c}{ Treatment } & \multirow{2}{*}{ SEM $^{2)}$} \\
\cline { 2 - 6 } & $\mathrm{A}^{1)}$ & $\mathrm{B}$ & $\mathrm{C}$ & $\mathrm{D}$ & $\mathrm{E}$ & $103^{\mathrm{a}}$ \\
\hline Initial Weight (g) & $100.49^{\mathrm{a}}$ & $99.04^{\mathrm{a}}$ & $104.20^{\mathrm{a}}$ & $101.23^{\mathrm{a}}$ & $102.03^{\mathrm{a}}$ & 1.02 \\
Final Body Weight (g) & $745.20^{\mathrm{b}}$ & $751.48^{\mathrm{b}}$ & $797.58^{\mathrm{a}}$ & $782.65^{\mathrm{a}}$ & $798.57^{\mathrm{a} 3)}$ & 31.74 \\
Weight Gain (g/day) & $11.53^{\mathrm{a}}$ & $11.65^{\mathrm{a}}$ & $12.38^{\mathrm{b}}$ & $12.19^{\mathrm{b}}$ & $12.44^{\mathrm{b}}$ & 0.32 \\
Feed Consumption (g/day) & $30.44^{\mathrm{a}}$ & $30.52^{\mathrm{a}}$ & $31.82^{\mathrm{a}}$ & $31.69^{\mathrm{a}}$ & $32.10^{\mathrm{a}}$ & 1.61 \\
Feed Conversion & $2.64^{\mathrm{a}}$ & $2.62^{\mathrm{a}}$ & $2.57^{\mathrm{a}}$ & $2.60^{\mathrm{a}}$ & $2.58^{\mathrm{a}}$ & 0.16 \\
\hline
\end{tabular}

Sukada, I. K., Puger, A. W., \& Nuriyasa, I. M. (2021). Performance of native chicken feed with different types of oil substitution. International Journal of Life Sciences, 5(3), 156-163. https://doi.org/10.53730/ijls.v5n3.1608 
Information :

1) Treatment of rations without using oil (A); using cooking oil (B); using palm oil (C); using fish oil (D); using pork oil (E)

2) Standard Error of the Treatment Means

3) Different letter superscript letters in the same line showed significant differences $(P<0.05)$

Treatment A resulted in final body weight (10 weeks of age) $745.20 \mathrm{~g}$, while treatment $\mathrm{B}$ was $0.84 \%$ higher $(\mathrm{P}>0.05)$ and treatments $\mathrm{C}, \mathrm{D}$, and $\mathrm{E}$ were $7.03 \%$, respectively; $5.03 \% ; 7.16 \%$ higher $(\mathrm{P}<0.05)$ compared to $\mathrm{A}$. The bodyweight of native chickens at the end of the study that received treatment $\mathrm{B}$ was not significantly different from treatment $A$. The body weight produced by the animal is closely related to feeding consumption. The higher the feed consumption, the higher the nutrient consumption as a constituent of body organs. Feed consumption is determined by feed palatability (De Marco et al., 2015; Sio et al., 2018). The use of used cooking oil is not much different in terms of palatability. This condition causes native chickens that receive feed containing used cooking oil is not significantly different compared to feed that does not use oil. Damage to cooking oil will affect the quality and nutritional value of fried foods. The oil that is damaged due to oxidation and polymerization processes will produce materials with an unpleasant taste (Budiarso, 2004). The bodyweight of chickens fed a diet containing palm oil, fish oil, and pork oil were higher than that of the feed without oil substitution (control). The oil in feed serves as a concentrated source of energy, essential fatty acids needed for growth. Oils are important components of steroids and phospholipids are used as precursors in the synthesis of certain vitamins and hormones. The use of oil can save dietary protein from being used as energy and limit ammonia production through a process called protein-sparing action. According to Setiati (2003), oil is a medium for dissolving and transporting vitamins A, D, E, and K which are beneficial for growth. Alice et al. (2006), stated that the lurid acid present in coconut oil has reduced viruses, reduced protozoa, antibacterial properties, and at the same time, increased body metabolism. Fish oil can increase feed palatability because the smell of fish oil is favored by poultry (Nuriyasa et al., 2021). Pork oil contains fat and fatty acids in addition to being a source of energy, it is also used by pigs to be used as a source of fatty acids which will be stored in fat tissues as a body energy reserve. As a source of energy, fats and oils are the biggest contributors to energy because 1 gram of fat will produce the equivalent of 9.30 kilocalories (kcal) or in 1 kilogram of fat will produce as well as 9300 kilocalories (kcal) of gross energy. Fats and oils are a chemically diverse group of compounds. Fats and oils are also a soluble medium for fat-soluble vitamins (A, D, E, and K) and antioxidants; such as phytosterols, tocopherols, and carotenoids, which help retain vitamins and stabilize fat (Sumadi, 2019).

The weight gain of chickens receiving treatment A was $11.53 \mathrm{~g} /$ day and the weight gain of chickens receiving treatment $\mathrm{B}$ was $1.04 \%$ higher but not significantly different $(\mathrm{P}>0.05)$. Treatment $\mathrm{C}, \mathrm{D}$, and $\mathrm{E}$ each 7.46\%; 5.72\%; and 7.89\% significantly higher than the control treatment. This condition was caused because the feed consumption between A and B was not significantly different and the feed consumption between A and $\mathrm{C}, \mathrm{D}$, and $\mathrm{E}$ was significantly different. The higher the feed consumption, the higher the nutrient consumption as a constituent of body tissues. Oil substitution in feed serves as a concentrated source of energy, essential fatty acids required for growth (Dibner et al., 1996).

Treatment A caused the consumption of rations in native chickens to be $30.44 \mathrm{~g} /$ day. Treatment $\mathrm{B}, \mathrm{C}, \mathrm{D}$, and $\mathrm{E}$ caused the consumption of rations of $0.26 \%$ respectively; $4.53 \% ; 4.11 \%$, and $5.45 \%$ higher but not statistically significantly different $(\mathrm{P}>0.05)$. The treatment of rations $\mathrm{B}, \mathrm{C}, \mathrm{D}$, and $\mathrm{E}$ caused the consumption of rations in native chickens to be higher than treatment $A$. This was because the energy content of the rations was the same so that it did not affect the consumption of rations. Quantitatively there was an increase in ration consumption in the treatment using oil with the treatment without using oil. Alice et al. (2006), stated that the presence of oil in animal feed can reduce ration dust, make it more attractive, enhance palatability and reduce the loss of nutrients due to dust. This condition causes quantitatively higher feed consumption.

The feed conversion of native chickens that received treatment A, B, C, D, and E were 2.64; 2.62; 2.57; 2.60; and 2.58 which were not statistically significant $(\mathrm{P}>0.05)$. The treatment using different oil substitutions in feed did not affect the ration conversion, due to the higher growth difference due to higher ration consumption, not due to differences in the efficiency of feed use. 


\section{Conclusion}

The results of the study concluded that the substitution of 3\% different oils in native chicken feed did not affect feed digestibility. Substitution of 3\% used cooking oil in the feed of native chickens aged 10 weeks did not affect performance; substitution of 3\% palm oil, $3 \%$ fish oil, $3 \%$ pork oil could improve the performance of native chickens aged 10 weeks.

Acknowledgments

We are grateful to two anonymous reviewers for their valuable comments on the earlier version of this paper.

Sukada, I. K., Puger, A. W., \& Nuriyasa, I. M. (2021). Performance of native chicken feed with different types of oil substitution. International Journal of Life Sciences, 5(3), 156-163. https://doi.org/10.53730/ijls.v5n3.1608 


\section{References}

Aidos, I., Jacobsen, C., Jensen, B., Luten, J. B., van der Padt, A., \& Boom, R. M. (2002). Volatile oxidation products formed in crude herring oil under accelerated oxidative conditions. European journal of lipid science and technology, 104(12), 808-818.

Amad, A. A., Männer, K., Wendler, K. R., Neumann, K., \& Zentek, J. (2011). Effects of a phytogenic feed additive on growth performance and ileal nutrient digestibility in broiler chickens. Poultry Science, 90(12), 28112816. https://doi.org/10.3382/ps.2011-01515

Bagiarta, W. I., Nuriyasa, M. I., \& Puger, W. A. (2017). Nutrient Diets Digestibility of Local Female rabbits (Lepus nigricollis) offered Grass Field Supplemented Multi Nutrient Block (MNB). International Journal of Agriculture Innovations and Research, 5, 2319-1473.

Boehringer, M. (1996). Lipoprotein in : Principles of Laboratory Medicine. Boehringer Mannheim Laboratory System.

Budiarso, I.T. (2004). Coconut Oil and Urine Alternative Medicine for HIV/AIDS.

De Marco, M., Martínez, S., Hernandez, F., Madrid, J., Gai, F., Rotolo, L., ... \& Schiavone, A. (2015). Nutritional value of two insect larval meals (Tenebrio molitor and Hermetia illucens) for broiler chickens: apparent nutrient digestibility, apparent ileal amino acid digestibility and apparent metabolizable energy. Animal Feed Science and Technology, 209, 211-218. https://doi.org/10.1016/j.anifeedsci.2015.08.006

Dibner, J. J., Kitchell, M. L., Atwell, C. A., \& Ivey, F. J. (1996). The effect of dietary ingredients and age on the microscopic structure of the gastrointestinal tract in poultry. Journal of Applied Poultry Research, 5(1), 7077. https://doi.org/10.1093/japr/5.1.70

Estévez, M., \& Cava, R. (2006). Effectiveness of rosemary essential oil as an inhibitor of lipid and protein oxidation: Contradictory effects in different types of frankfurters. Meat Science, 72(2), 348-355. https://doi.org/10.1016/j.meatsci.2005.08.005

Geng, A. L., Liu, H. G., Zhang, Y., Zhang, J., Wang, H. H., Chu, Q., \& Yan, Z. X. (2020). Effects of indoor stocking density on performance, egg quality, and welfare status of a native chicken during 22 to 38 weeks. Poultry science, 99(1), 163-171. https://doi.org/10.3382/ps/pez543

Haunshi, S., Niranjan, M., Shanmugam, M., Padhi, M. K., Reddy, M. R., Sunitha, R., ... \& Panda, A. K. (2011). Characterization of two Indian native chicken breeds for production, egg and semen quality, and welfare traits. Poultry Science, 90(2), 314-320. https://doi.org/10.3382/ps.2010-01013

Jayasena, D. D., Jung, S., Kim, H. J., Yong, H. I., Nam, K. C., \& Jo, C. (2015). Taste-active compound levels in Korean native chicken meat: The effects of bird age and the cooking process. Poultry science, 94(8), 19641972. https://doi.org/10.3382/ps/pev154

Lichtenstein, A. H., Appel, L. J., Brands, M., Carnethon, M., Daniels, S., Franch, H. A., ... \& Wylie-Rosett, J. (2006). Diet and lifestyle recommendations revision 2006: a scientific statement from the American Heart Association Nutrition Committee. Circulation, 114(1), 82-96.

Mountzouris, K. C., Tsitrsikos, P., Palamidi, I., Arvaniti, A., Mohnl, M., Schatzmayr, G., \& Fegeros, K. (2010). Effects of probiotic inclusion levels in broiler nutrition on growth performance, nutrient digestibility, plasma immunoglobulins, and cecal microflora composition. Poultry science,89(1), 58-67. https://doi.org/10.3382/ps.2009-00308

Nuriyasa, I. M., Puger, A. W., \& Putra, I. G. A. A. (2021). Effects of dietary different lipid sources on serum cholesterol concentration, fat composition and growth performance in duckss. Adv. Anim. Vet. Sci, 9(6), 926-932.

Puger, A. W., \& Nuriyasa, I. M. (2019). Ration digest value and performance of male Bali ducks feed waste wine fermented with different levels. International journal of life sciences, 3(3), 1-7.

Setiati, S. (2003). Free radicals, Antioxidants and Aging process. MajalahMedika: Jakarta, Ed, 6, 366-368.

Sio, S., Sikone, H. Y., \& Usboko, C. A. (2018). Nutrient digestion and body weight gain of Balinese cows getting basic ration of spear grass and rosewood leaves supplemented with falcata tree leaves. International Journal of Life Sciences, 2(2), 1-11.

Sumadi. (2019). Pig Livestock Nutrition. Nulus Private Publisher, Denpasar, Bali

Yegani, M., \& Korver, D. R. (2008). Factors affecting intestinal health in poultry. Poultry science, 87(10), 20522063. https://doi.org/10.3382/ps.2008-00091 
Zhang, Y., Li, C., Jia, D., Zhang, D., \& Zhang, X. (2015). Experimental evaluation of MoS2 nanoparticles in jet MQL grinding with different types of vegetable oil as base oil.Journal of Cleaner Production, 87, 930-940. https://doi.org/10.1016/j.jclepro.2014.10.027

\section{Biography of Authors}

\begin{tabular}{|l|l||}
\hline & $\begin{array}{l}\text { Dr. Ir. I Ketut Sukada, M.Si Was born in Tanjung Benoa, Bali, Indonesia, 21 Meiu } \\
\text { 1957. He is an associate professor, Faculty of Animal Science, Udayana University, } \\
\text { at Jimbaran District, Badung Regency, Indonesia. Currently, the author is still } \\
\text { active as teaching staff in the S1, S2, and S3 in the Faculty of Animal Husbandry } \\
\text { Study Programs, as well as the Professional Engineer Program at Udayana } \\
\text { University. The author is active in research and service activities and publishes the } \\
\text { results of his activities in various scientific meetings and national and } \\
\text { international journals. Hp.WA:082146495250 } \\
\text { Email: sukada@unud.ac.id }\end{array}$ \\
\hline $\begin{array}{l}\text { Ir. Anthonius Wayan Puger, MS. Was born in Tangeb, Bali, Indonesia, on 25 } \\
\text { January 1958. He is a Lecturer in the Faculty of Animal Science, Udayana } \\
\text { University, at Jimbaran District, Badung Regency, Indonesia. Currently, the author } \\
\text { is still active as teaching staff in the S1, S2 Faculty of Animal Husbandry Study } \\
\text { Programs, as well as the Professional Engineer Program at Udayana University. } \\
\text { The author is active in research and service activities and publishes the results of } \\
\text { his activities in various scientific meetings and national and international journals. } \\
\text { Hp.WA:08123995907. } \\
\text { Email: anton.puger@gmail.com }\end{array}$ \\
$\begin{array}{l}\text { Dr. Ir. I Made Nuriyasa, MS was born in Tabanan on 20th January 1962. He is an } \\
\text { associate professor. Career Lecturers began in 1987, as a lecturer in Animal } \\
\text { Nutrition at the Faculty of Animal Husbandry, Udayana University. Currently, the } \\
\text { author is still active as teaching staff in the S1, S2, S3 Faculty of Animal Husbandry } \\
\text { Study Programs, as well as the Professional Engineer Program at Udayana } \\
\text { University. The author is active in research and service activities and publishes the } \\
\text { results of his activities in various scientific meetings and national and } \\
\text { international journals. } \\
\text { Hp.WA: 082237230123 } \\
\text { Email: madenuriyasa@unud.ac.id }\end{array}$ \\
\hline
\end{tabular}

Sukada, I. K., Puger, A. W., \& Nuriyasa, I. M. (2021). Performance of native chicken feed with different types of oil substitution. International Journal of Life Sciences, 5(3), 156-163. https://doi.org/10.53730/ijls.v5n3.1608 